\title{
Dental metric variability associated with human migration from skeletal remains of two Jomon sites (Yoshigo and Inariyama) in the Atsumi Peninsula area
}

\author{
Wataru MORITA $^{1 *}$, Soichiro KUSAKA ${ }^{1}$, Wataru YANO $^{2}$, Masato NAKATSUKASA ${ }^{1}$ \\ ${ }^{1}$ Laboratory of Physical Anthropology, Department of Zoology, Graduate School of Science, Kyoto University, \\ Kyoto 606-8502, Japan \\ ${ }^{2}$ Primate Research Institute, Kyoto University, Inuyama 484-8506, Japan
}

Received 28 April 2011; accepted 13 December 2011

\begin{abstract}
This study investigated interpopulation genetic relationships in the Jomon Atsumi Peninsula area, comparing the pattern of human migration revealed by strontium isotope ratio with dental metric variation of Yoshigo and Inariyama skeletal remains. Morphological differences were evaluated between the local and immigrant groups to determine whether or not local populations had become completely homogenized by human migration. We have constructed $4 \times 4$ contingency tables consisting of four clusters derived from $K$-means clustering of dental measurements and four groups (immigrants and locals of the two sites), and evaluated their correlations by Fisher's exact test. The results revealed that human migration pattern was significantly correlated with dental metric variation, suggesting that there was regional heterogeneity among Jomon populations in the Atsumi Peninsula area. Although the distinction between immigrants and locals of Yoshigo and Inariyama populations based on strontium isotope analysis was not completely in accord with dental metric variability, most of the identified immigrants exhibited dental profiles that were beyond each local profile as determined using principal component analysis. Furthermore, the dental metric variances of the immigrants were significantly larger than those of the locals, suggesting multiple origins. The microdifferentiation among populations in the Atsumi Peninsula area may suggest nonrandom kin-structured migration and/or population aggregation from surrounding areas.
\end{abstract}

Key words: dental metric, within-group variation, Jomon period, strontium isotope, migration

\section{Introduction}

The Jomon period spanned from 13000 to 2300 years BP in the Japanese archipelago (Imamura, 1996a; Habu, 2004). The Jomon people were Neolithic hunter-gatherers who are well known for their cord-marked pottery. They generally led a sedentary life and effectively exploited marine and terrestrial resources. In the Late to Final Jomon period (c. 40002300 years BP), the Jomon population declined due to climatological cooling and associated environmental changes (Koyama, 1978); during this period the Jomon developed ritual practices and artifacts but did not drastically change their subsistence strategies (Imamura, 1996a; Habu, 2004). The Jomon culture eventually ended with waves of migration of agriculturalists with wet rice cropping from continental East Asia, except for Hokkaido (Imamura, 1996b; Chisholm and Koike, 1999; Tsude, 2001; Kobayashi et al., 2004).

* Correspondence to: Wataru Morita, Laboratory of Physical Anthropology, Department of Zoology, Graduate School of Science, Kyoto University, Kitashirakawa Oiwake-cho, Sakyo-ku, Kyoto 606-8502, Japan.

E-mail: morita@anthro.zool.kyoto-u.ac.jp

Published online 17 February 2012

in J-STAGE (www.jstage.jst.go.jp) DOI: 10.1537/ase.110428
The Atsumi Peninsula area (the Atsumi Peninsula and the surrounding area of the Tokai region located in the central part of the Japanese archipelago) is one of the areas where many Jomon shell mounds are situated. In this region, the number of shell mounds began to increase from the beginning of the Late Jomon period (c. 4000-3000 years BP), and many of them were formed during the Final Jomon period (c. 3000-2300 years BP). Despite the general population decline through the Late to Final Jomon period, the Tokai region still retained a greater population density than the eastern Chubu and Kanto regions, and western Japan (Koyama and Sugito, 1984).

The shell mounds in the Atsumi Peninsula area are characterized by an extremely large number of human burials. Most of these skeletons were excavated in the 1920s and became important materials for the early study of the origins of the modern Japanese (Kiyono, 1925, 1928). It is also notable that these sites revealed interesting ritual and burial customs such as tooth ablation practices, tooth filing, and squaredshaped bone-pile burial (banjo-shuseki-bo), spurring many archeological studies on the social organization and mortuary habits of the Jomon people (Harunari, 1979, 1986; Tanaka, 2001; Funahashi, 2008). Jomon people from the Final period, especially around eastern Japan, are thought to have had a transegalitarian society in which socioeconomic 
inequalities were recognized (Hayden, 1995; Takahashi, 2004). Watanabe (1990) proposed that occupational differentiation had appeared in the Jomon society, on the basis of an ethnographic comparison with recent sedentary huntergatherers. The presence of interfamilial occupational differentiation (hunting vs. fishing) of the Jomon people in the Atsumi Peninsula has been supported by carbon, nitrogen, and strontium isotope analyses (Kusaka et al., 2008, 2011), suggesting an increased social complexity in the Final Jomon period.

Hints for reconstructing past social structures can also be obtained from biodistance analysis, which employs phenotypic data as proxies for underlying genotypic variation to define relatedness or divergence between populations (Larsen, 1997, 2002). Interpopulation phenotypic variation is formed through genetic drift (human settlement, population growth/decline) and gene flow (human migration) (Lane and Sublett, 1972; Spence, 1974; Konigsberg and Buikstra, 1995; Stojanowski and Schillaci, 2006). Matsumura's (2000) dental metric study on skeletal remains from four sites in the Atsumi Peninsula area (the Yoshigo, Inariyama, Ikawazu and Hobi shell mounds) revealed that most of the individuals from these four sites did not form clear sitespecific clusters, although some individuals from a given site formed tight clusters, which might have reflected close kinship. This result raises two different possibilities. The first one is that genetically homogeneous populations had been dispersed in this area before the Late Jomon period. The second one is that local gene pools had not been totally homogenized but mutual human migration masked morphological distinction between populations.

Analysis of phenotypic variation alone cannot decide between these two possibilities. Kusaka et al. (2009, 2011) made distinctions between 'locals' and 'immigrants' in subsamples of the Yoshigo and Inariyama populations by strontium isotope analysis of the tooth enamel. Strontium isotope analysis is an effective tool to reveal prehistoric human migration patterns (e.g. Ezzo et al., 1997; Price et al., 2002; Bentley et al., 2007; Knudson and Price, 2007; Montgomery et al., 2007). Tooth enamel records the $\mathrm{Sr}$ isotope ratio $\left.{ }^{87} \mathrm{Sr} /{ }^{86} \mathrm{Sr}\right)$ in the environment where the person lived during the formative period of the tooth enamel, and undergoes little subsequent change. Therefore, when people migrate between geochemically contrasting residential areas, the $\mathrm{Sr}$ isotope signatures in the tooth enamel of immigrants are detectable (Bentley, 2006). In the Atsumi Peninsula area, the strontium isotope ratio exhibits little variation in each local area around the site, and large differences of regional strontium isotope ratio exist (Kusaka et al., 2009, 2011). Since the observed strontium isotope ratios in tooth enamel are sufficiently contrasted between locals and immigrants, immigrants of populations in the Atsumi Peninsula area can be successfully identified. Although the 'local group' determined by the strontium isotope ratio may include immigrants who came from a place with the same geochemical signature as the excavated site, these determinations help us to evaluate morphological similarity/dissimilarity between the local group and immigrants. Genetic variability among populations is affected by local demographic variables, an in particular by human migration patterns and frequencies.
Recently, biodistance studies have been employed to reveal intrasite genetic variation (Buikstra et al., 1990; Stojanowski and Schillaci, 2006). This technique has been applied several times to Jomon populations (Kondo, 1994; Matsumura et al., 1996; Matsumura and Nishimoto, 1996) and has also been cross-checked against ancient DNA data (Shinoda et al., 1998; Adachi et al., 2003, 2006). Although the exact nature of genealogical relationships among individuals can be rarely specified without a priori knowledge, biodistance analysis can reveal relative relatedness among them (Stojanowski and Schillaci, 2006). If morphological distinction is not observed between the local and immigrant groups, a whole population in an area would in fact be genetically homogeneous. On the other hand, if any morphological distinction is found, this indicates that human migration between populations had not completely homogenized local gene pools.

The purpose of the present study is to reveal interpopulation genetic relationships in the Atsumi Peninsula area, by comparing dental metric variation to human migration based on strontium isotope analysis of Yoshigo and Inariyama Jomon skeletal remains. This study represents a synthesis of biological relationships within and between populations and archeological contexts to reconstruct the biocultural structure in the Atsumi Peninsula area, using information uniquely available from strontium isotope analysis.

\section{Materials and Methods}

The materials examined in this study consisted of human skeletal remains from the Yoshigo and Inariyama shell mounds in the Atsumi Peninsula area (Figure 1, Table 1). These skeletal series are housed in the Laboratory of Physical Anthropology, Graduate School of Science, Kyoto University. The Yoshigo shell mound is located on the northern coast of the Atsumi Peninsula, Aichi Prefecture. In 1922, K. Kiyono excavated this site and recovered about 300 human skeletons (Kiyono, 1969). The formation of the Yoshigo site covers the later part of the Late Jomon period and the Final Jomon period (c. 3500-2300 BP), based on the chronology of pottery types (Yamanouchi, 1952). This chronology was confirmed by radiocarbon dating of human bone collagen (c. 3200-2800 cal BP; Kusaka et al., 2009). The Inariyama shell mound is located on the Toyohashi Plain, Aichi Prefecture. This site was also excavated in 1922, and about 60 human skeletons were recovered (Kiyono, 1969). The age of Inariyama is thought to be the middle and late part of the Final Jomon period (c. 2800-2300 BP) based on the chronology of pottery types. The radiocarbon dates of remains from the Inariyama shell mound have not been investigated. Age and sex, and the distinction between immigrant and local skeletal remains as well as cut-off values of local strontium isotope ratios are given in Kusaka et al. (2009, 2011). Figure 2 illustrates the strontium isotope ratios of tooth enamel of Yoshigo and Inariyama skeletal remains showing a distinction between locals and immigrants. Eight out of 24 individuals of Yoshigo and 3 out of 10 individuals of Inariyama were identified as immigrants (Figure 2).

Dental crown metrics have been favored for use in biodistance analysis (e.g. Larsen, 1997; Pietrusewsky, 2000; 


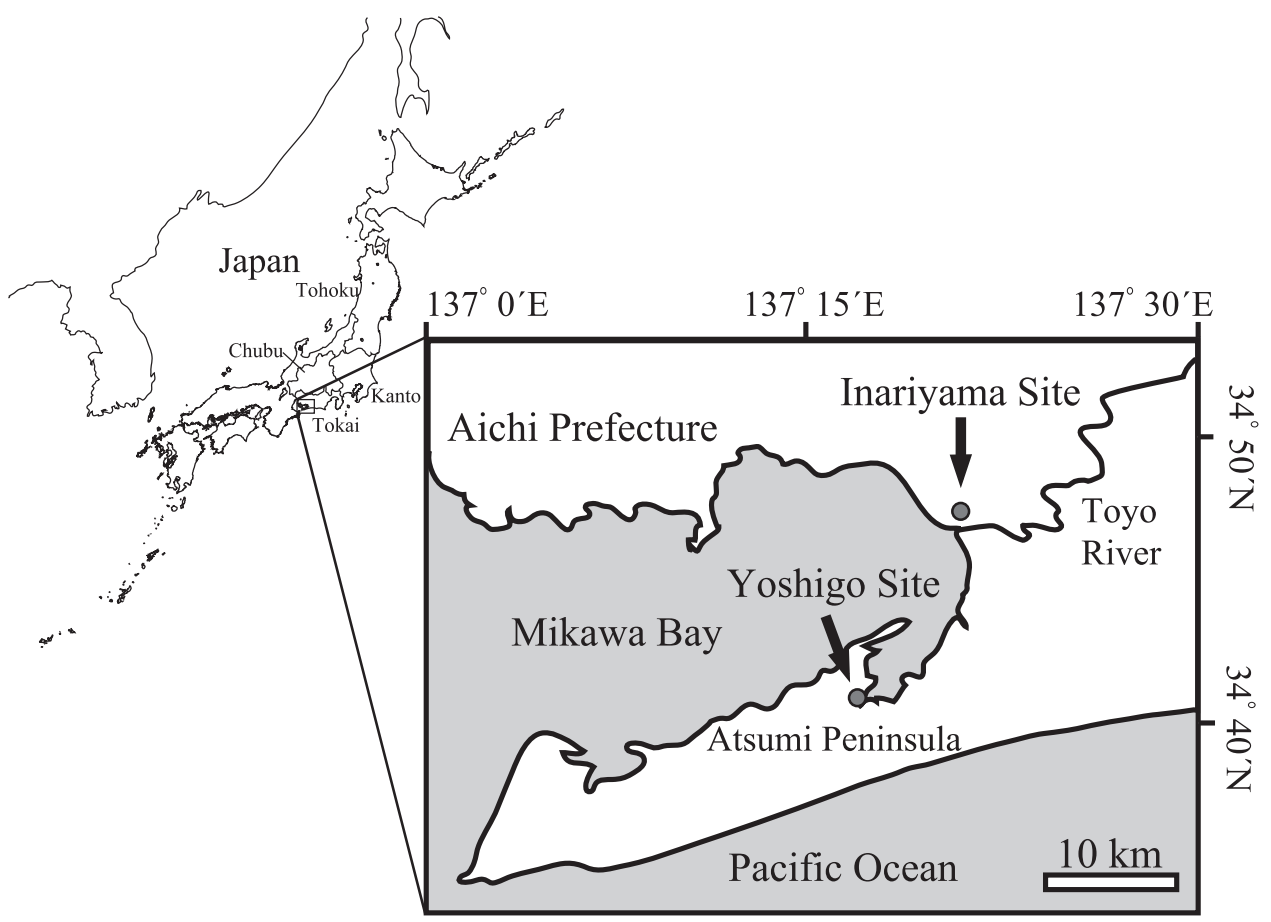

Figure 1. Map of the study area showing the location of the Yoshigo and Inariyama shell mounds.

Stojanowski and Schillaci, 2006) because of the moderate to high degree of heritability (Kieser, 1990; Scott, 1991; Dempsey and Townsend, 2001), absence of remodeling after crown completion, and generally better preservation of the crown (Hillson, 1996; Scott and Turner, 1997). All of the dental measurements used in this study were collected by one of the authors (W.M.), using digital calipers. Mesiodistal (MD) and buccolingual (BL) measurements were made following the methodology of Fujita (1949). Basically, measurements of the right teeth were used for statistical analyses. However, when the right side tooth was missing, measurements from the left antimere were substituted. Any dental measurement that was potentially affected by dental wear, calculus, and caries was treated as missing data. To ensure accuracy, each measurement was made three times, and its mean value was used. The multivariate analyses require a complete data set for each individual, but this is a hard condition to fulfill for Jomon samples because of heavy attrition, tooth ablation, dental caries, and so on. After testing for normality for each measurement, we removed individuals for which too few measurements were available, and measurements which were taken on too few individuals from the data set to achieve a good balance between the number of samples and that of variables in a stepwise fashion. Finally, we used eight measurements (UP2MD, UP2BL, UM1MD, UM1BL, LP2MD, LP2BL, LM1MD, and LM1BL) from 34 individuals (Table 2).

Before using univariate and multivariate statistical methods, all measurements were size-standardized by a Q-mode correction whereby each dental measurement was divided by the geometric mean for all the measurements for each individual in the sample (Corruccini, 1973; Darroch and Mosimann, 1985; Powell and Neves, 1999; Scherer, 2007;
Temple et al., 2011). To eliminate sex-related size variation while retaining shape variation, geometric means were derived by multiplying together all the variables for each individual and calculating the $n$th root of this product ( $n=$ number of variables for the individual).

Firstly, to examine the association between dental metric variation and the difference of the childhood home based on strontium isotope ratio, all samples were divided into four clusters by $K$-means clustering of dental measurements (Hartigan and Wong, 1979). Then, these four clusters were fitted to four groups: Yoshigo immigrant, Yoshigo local, Inariyama immigrant, and Inariyama local. The significance of the deviation from a null hypothesis consisting of the absence of contingency between them was evaluated by Fisher's exact test $(\alpha=0.05)$ since the sample size was small.

Secondly, principal component analysis (PCA) was carried out using size-standardized dental measurements, to examine patterns of phenotypic variability between immigrants and locals based on a human migration model. The principal components ( $\mathrm{PCs}$ ) are ranked by the amount of the total variance that each of them explains. PCA can then be used as a data reduction technique that generates new variables from the original datasets. Individuals that occupy a similar space in the PCA plots are morphologically similar and are considered to be, to some degree, genetically similar because phenotypic covariance, which was calculated from standardized variables for all specimens in the present study, is related to genetic covariance (Chevrud, 1988; WilliamsBlangero and Blangero, 1989). After plotting all samples by the first two or three PCA scores, we determined 95\% confidence ellipses of Yoshigo and Inariyama locals using a principal axis method (Sokal and Rohlf, 1995). This method allowed us to assess whether or not immigrants of each site 
Table 1. Yoshigo and Inariyama human skeletal remains used in this study

\begin{tabular}{|c|c|c|c|c|c|c|}
\hline Sample No. & Sex & Age at death & Local vs. immigrant ${ }^{1}$ & $\begin{array}{l}K \text {-means } \\
\text { clustering }\end{array}$ & $\begin{array}{l}\text { Individual location } \\
\text { in Figure } 3\end{array}$ & $\begin{array}{l}\text { Individual location } \\
\text { in Figure } 4\end{array}$ \\
\hline \multicolumn{7}{|c|}{ Yoshigo shell mound } \\
\hline 280 & Male & Adolescent & Local & 4 & Yoshigo $^{2}$ & Yoshigo $^{2}$ \\
\hline 302 & Female & Young adult & Local & 3 & Yoshigo & Yoshigo \\
\hline 310 & Female & Young adult & Local & 4 & Yoshigo $^{2}$ & Yoshigo $^{2}$ \\
\hline 316 & Male & Young adult & Immigrant & 2 & Outlier & Yoshigo \\
\hline 333 & Male & Young adult & Immigrant & 1 & Outlier & Outlier \\
\hline 349 & Male & Young adult & Immigrant & 1 & Outlier & Outlier \\
\hline 352 & Female & Adolescent & Local & 2 & Yoshigo $^{2}$ & Yoshigo $^{2}$ \\
\hline 363 & Male & Middle adult & Immigrant & 3 & Yoshigo & Yoshigo \\
\hline 375 & Male & Young adult & Local & 2 & Yoshigo $^{2}$ & Yoshigo $^{2}$ \\
\hline 383 & Male & Middle adult & Immigrant & 3 & Outlier & Yoshigo \\
\hline 386 & Male & Young adult & Local & 3 & Yoshigo & Yoshigo \\
\hline 388 & Male & Young adult & Local & 2 & Yoshigo $^{2}$ & Yoshigo \\
\hline 396 & Male & Young adult & Local & 2 & Yoshigo & Yoshigo \\
\hline 404 & Female & Adolescent & Local & 4 & Yoshigo $^{2}$ & Yoshigo $^{2}$ \\
\hline 408 & Female & Adult & Immigrant & 4 & Yoshigo $^{2}$ & Outlier \\
\hline 435 & Male & Young adult & Local & 2 & Yoshigo $^{2}$ & Yoshigo $^{2}$ \\
\hline 460 & Female & Young adult & Immigrant & 2 & Yoshigo & Yoshigo \\
\hline 481 & Male & Middle adult & Local & 2 & Yoshigo & Yoshigo \\
\hline 488 & Female & Middle adult & Immigrant & 3 & Yoshigo $^{2}$ & Yoshigo \\
\hline 509 & Male & Middle adult & Local & 3 & Yoshigo & Yoshigo \\
\hline 522 & Female & Young adult & Local & 2 & Yoshigo $^{2}$ & Yoshigo \\
\hline 523 & Female & Young adult & Local & 2 & Yoshigo $^{2}$ & Yoshigo $^{2}$ \\
\hline 540 & Female & Middle adult & Local & 2 & Yoshigo & Outlier \\
\hline 541 & Female & Young adult & Local & 2 & Yoshigo & Yoshigo \\
\hline \multicolumn{7}{|c|}{ Inariyama shell mound } \\
\hline 210 & Unknown & Adolescent & Local & 4 & Inariyama & Inariyama \\
\hline 217 & Female & Young adult & Immigrant & 2 & Outlier $^{3}$ & Outlier $^{3}$ \\
\hline 224 & Female & Middle adult & Local & 4 & Inariyama & Inariyama \\
\hline 228 & Female & Adolescent & Local & 4 & Inariyama & Inariyama \\
\hline 231 & Male & Young adult & Immigrant & 2 & Outlier & Inariyama \\
\hline 232 & Male & Young adult & Local & 4 & Inariyama & Inariyama \\
\hline 236 & Male & Adolescent & Local & 4 & Inariyama & Inariyama \\
\hline 238 & Male & Young adult & Local & 4 & Inariyama & Inariyama \\
\hline 241 & Male & Middle adult & Immigrant & 2 & Outlier ${ }^{3}$ & Outlier ${ }^{3}$ \\
\hline 251 & Male & Young adult & Local & 2 & Inariyama & Inariyama \\
\hline
\end{tabular}

${ }^{1}$ Based on strontium isotope analysis (Kusaka et al., 2009, 2011).

${ }^{2}$ And also included in dental distribution for Inariyama locals.

${ }^{3}$ And also included in dental distribution for Yoshigo locals.

fell within the range of local dental variations. The results of this method were compared with the estimation of the childhood home based on the strontium isotope data.

If immigrants had originated from multiple populations, the variance of immigrants would be larger than that of locals. To estimate the difference of phenotypic variability between immigrants and locals, both univariate and multivariate data analyses were conducted. For each Q-mode transformed dental metric variable, the difference of withingroup variance between immigrants and locals was tested using a univariate $F$-test (Manly, 1994). Before the $F$-test, normality was confirmed by the Kolmogorov-Smirnov test $(\alpha=0.05)$. Due to the small sample size, we bootstrapped the sample standard deviations to obtain bias-free estimates of variance (Efron, 1981). The $F$-test was conducted using variances for all bias-corrected variables.

For multivariate data analysis, the determinant of the variance-covariance matrix was calculated (Green, 1976; Konigsberg, 1988; Schillaci and Stojanowski, 2003). Pairwise determinant ratios between immigrants and locals were evaluated for statistical significance, using a nonparametric bootstrap method (Petersen, 2000). The data were resampled (9999 iterations) after random shuffling with sizes equal to the original sample sizes to generate a randomized distribution of determinant ratio values. The $P$-value was calculated by dividing the number of resampled values greater than or equal to the observed determinant ratio plus one by the number of resamplings plus one (Manly, 1997; Petersen, 2000). The ratio of determinants is supposed to be one when equal mobility between the two groups exists (Konigsberg, 1988). When a numerator group is more mobile, the determinant ratio is positive, and vice versa. In this procedure, to avoid generating singular variance-covariance matrices, the number of variables is limited to $n-1$, where $\mathrm{n}$ is the sample size of the smallest group. The number of Yoshigo immigrants $(n=8)$, Inariyama immigrants $(n=3)$, and locals $(n=7)$ were equal to or less than that of the eight variables. Then, variable reduction was achieved using a PCA method within Yoshigo and Inariyama samples, respectively. In the case of Yoshigo, the first seven PCA scores, which contributed to 


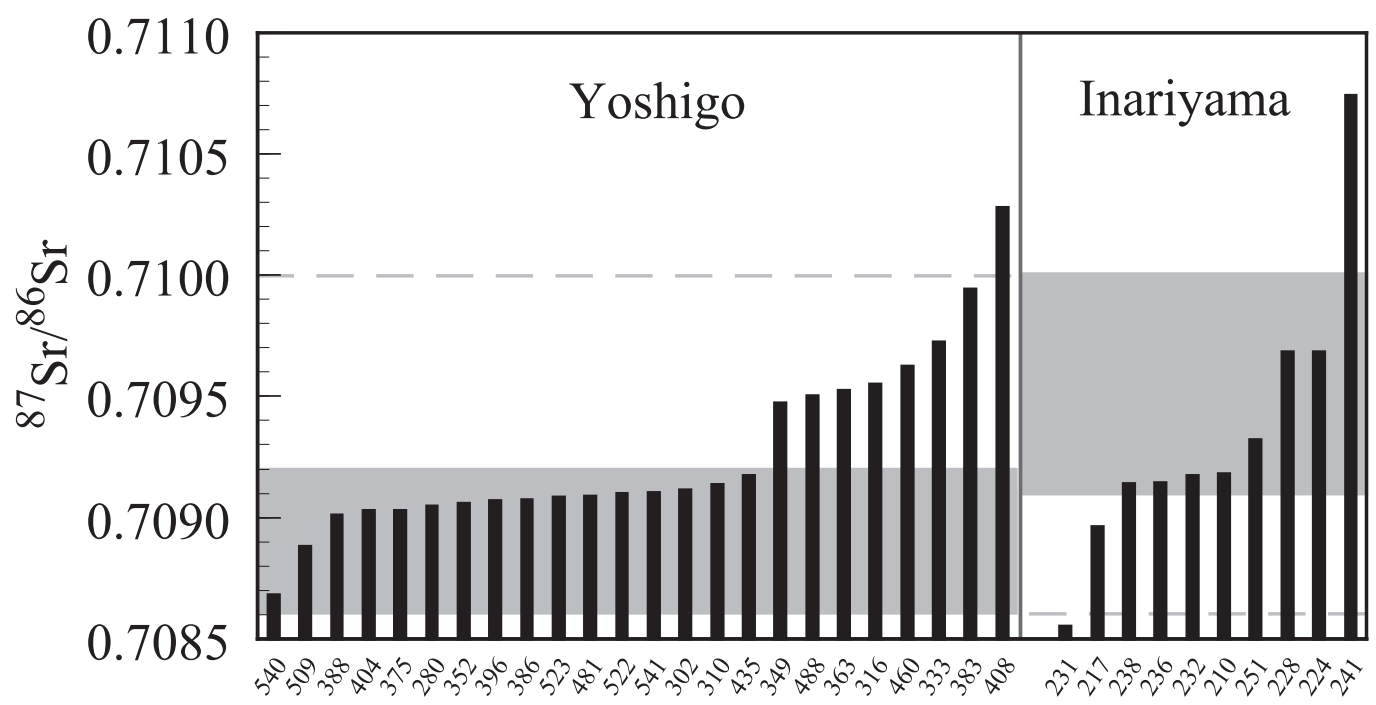

Figure 2. Strontium isotope ratios of Yoshigo and Inariyama individuals. The gray horizontal range indicates the local range for Yoshigo (0.7086-0.7092) and Inariyama (0.7091-0.7100). The value of No. 231 (0.7066) was changed to reduce the scale. Data from Kusaka et al. (2009, 2011).

Table 2. Mean and standard deviation of the dataset

\begin{tabular}{|c|c|c|c|c|c|c|c|c|c|c|c|c|c|c|c|c|}
\hline & \multicolumn{2}{|c|}{ UP2MD } & \multicolumn{2}{|c|}{ UP2BL } & \multicolumn{2}{|c|}{ UM1MD } & \multicolumn{2}{|c|}{ UM1BL } & \multicolumn{2}{|c|}{ LP2MD } & \multicolumn{2}{|c|}{ LP2BL } & \multicolumn{2}{|c|}{ LM1MD } & \multicolumn{2}{|c|}{ LM1BL } \\
\hline & Mean & SD & Mean & SD & Mean & SD & Mean & SD & Mean & SD & Mean & SD & Mean & SD & Mean & SD \\
\hline & 6.46 & & & & & & & & & & & & & & & 0.48 \\
\hline Inar & 6.58 & 0.28 & 8.88 & 0.25 & 10.32 & 0.47 & 11.59 & 0.37 & 7.07 & 0.40 & 8.40 & 0.44 & 11.64 & 0.49 & 11.22 & 0.65 \\
\hline Total & 6.49 & 0.33 & 8.94 & 0.49 & 10.20 & 0.49 & 11.84 & 0.49 & 6.97 & 0.41 & 8.30 & 0.48 & 11.57 & 0.50 & 11.15 & 0.52 \\
\hline
\end{tabular}

$99.9 \%$ of the total variance, were utilized for the determinant ratio analysis. In the case of Inariyama, the first two PCA scores, which contributed to $68.8 \%$ of the total variance, were used for the determinant ratio analysis. All statistical analyses were carried out using R.2.9.1 (R Development Core Team, 2009).

\section{Results}

The classification of individuals derived from $K$-means clustering is presented in Table 1 . Contingency tables between four clusters of dental measurements and four groups based on strontium isotope analysis are presented in Table 3. The results of Fisher's exact test showed that human migration significantly deviated from the null hypothesis $(P=$ $0.004)$. This finding suggests that the dental metric variation of Yoshigo and Inariyama skeletal remains is significantly explained by human migration among populations in the Atsumi Peninsula area. Thus, human migration between populations had not completely homogenized local gene pools and most of immigrants who had come from other population had different genetic backgrounds from the locals.

The plot of the first three PC scores for the eight variables across all samples is presented in Figure 3 and Figure 4. The first three PCs have eigenvalues greater than 1.0 and account for $74.1 \%$ of the total variance. Figure 3 and Figure 4 show a general trend that immigrants had larger variability and locals had smaller variability. In Figure 3, four out of eight Yoshigo immigrants (Nos. 316, 333, 349, and 383) and all of
Table 3. Four by four contingency table consisting of four clusters derived from $K$-means clustering and four groups based on strontium isotope analysis

\begin{tabular}{lccccc}
\hline & Cluster 1 & Cluster 2 & Cluster 3 & Cluster 4 & Total \\
\hline $\begin{array}{c}\text { Yoshigo } \\
\text { immigrant }\end{array}$ & 2 & 2 & 3 & 1 & 8 \\
$\begin{array}{c}\text { Yoshigo } \\
\text { local }\end{array}$ & 0 & 10 & 3 & 3 & 16 \\
$\begin{array}{c}\text { Inariyama } \\
\text { immigrant } \\
\text { Inariyama } \\
\text { local }\end{array}$ & 0 & 3 & 0 & 0 & 3 \\
Total & 2 & 16 & 6 & 10 & 34 \\
\hline
\end{tabular}

Fisher's exact test, $P=0.004$.

the Inariyama immigrants (Nos. 217, 231, and 241) fell outside the $95 \%$ confidence ellipse of each local group. Two of the Yoshigo immigrants (Nos. 408 and 488) and two of the Inariyama immigrants (Nos. 217 and 241) were plotted in the confidence ellipses for the Inariyama and Yoshigo local groups, respectively. In Figure 4, three of the Yoshigo immigrants (Nos. 333, 349, and 408) and two Inariyama immigrants (Nos. 217 and 241) exhibited dental profiles that were beyond the confidence ellipses for the each local group. These two Inariyama immigrants were also fitted well within the dental distribution of the Yoshigo local group. Additionally, one local of Yoshigo (No. 540) was far apart from the confidence ellipses for the other Yoshigo locals. In total, 8 out of 11 immigrants were beyond the respective local 


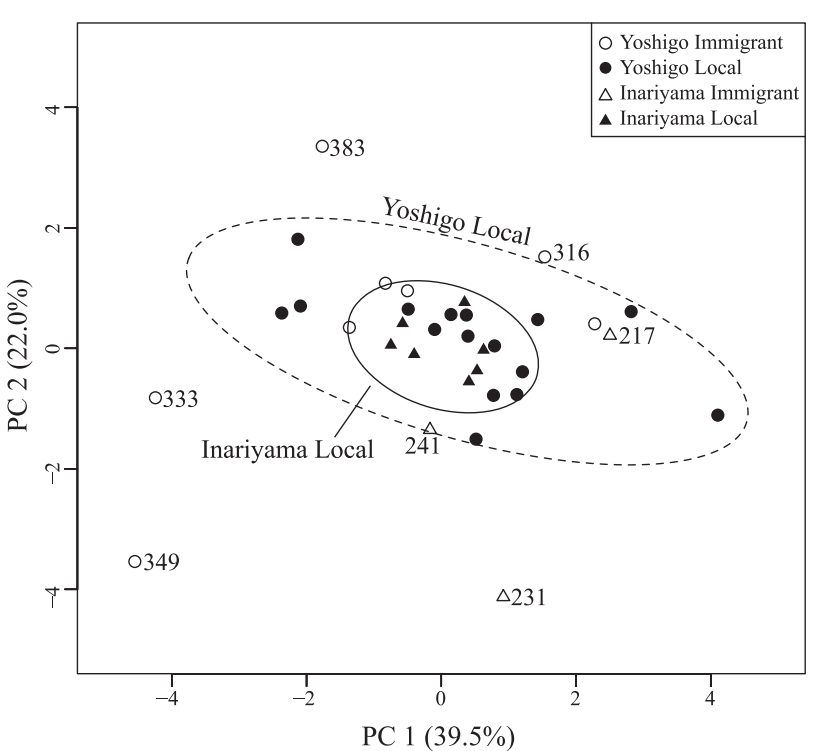

Figure 3. First and second principal components plot of all samples and 95\% confidence ellipses for Yoshigo and Inariyama locals using eight Q-mode corrected variables.

dental profile for the first three PC scores.

The results of bootstrapped estimates of standard deviations and $F$-test $P$-values for the Yoshigo population between the immigrants and the locals are presented in Table 4. The immigrants exhibit larger standard deviations for six out of eight variables, and two of these differences were statistically significant. Although it was not true for all of the variables, a general trend of greater immigrant variance was indicated by larger bias-corrected standard deviations for the majority of variables.

The bootstrapped estimates of the within-group standard deviations and $F$-test $P$-values for the Inariyama population between the immigrants and the locals are presented in Table 5 . The greater immigrant variability was also indicated by the larger standard deviations for six out of eight variables, with three of them significant. Larger variability was also observed in Inariyama immigrants.

Table 6 shows the results of determinant ratio analysis as a means of multivariate evaluation of within-group variation between immigrants and locals. The determinant of the

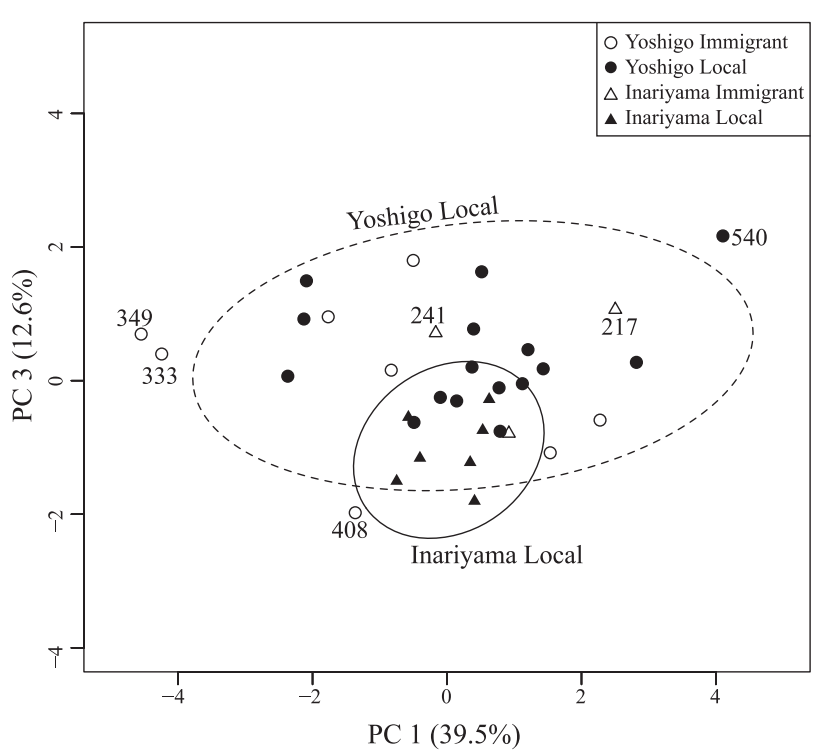

Figure 4. First and third principal components plot of all samples and $95 \%$ confidence ellipses for Yoshigo and Inariyama locals using eight Q-mode corrected variables.

variance-covariance matrix could be utilized as a generalized variance measure (Green, 1976). Generally, a population with a greater number of immigrants will show a large determinant. It was expected that the immigrant group would have a larger determinant than its local group, and the determinant ratio between immigrants and locals exceeds 1.0.

The randomization probability indicated a significant departure from a determinant ratio of 1 at the $\alpha=0.05$ level for the Yoshigo shell mounds. In the case of Inariyama, the determinant ratio exceeded 1.0, and resampling analysis also found a significant difference in the amount of variability between the immigrants and the locals. It is concluded that the local group had quite small diversity relative to the immigrant group in both populations (Figure 3, Figure 4).

Most of the immigrants were excluded from the confidence ellipses of local variation, and the variances of immigrants were significantly larger than those of locals, suggesting that immigrants came from multiple groups which were genetically segregated from each other.

Table 4. Univariate variance tests for Yoshigo population

\begin{tabular}{|c|c|c|c|c|c|c|c|c|c|}
\hline \multirow{2}{*}{ Variable } & \multicolumn{3}{|c|}{ Immigrant $(n=8)$} & \multicolumn{3}{|c|}{ Local $(n=16)$} & \multirow{2}{*}{$F$-value } & \multirow{2}{*}{$P$-value } & \\
\hline & SD & Boot & Bias & SD & Boot & Bias & & & \\
\hline UP2MD & 0.040 & 0.037 & 0.003 & 0.025 & 0.024 & 0.001 & 2.43 & 0.070 & \\
\hline UP2BL & 0.074 & 0.070 & 0.004 & 0.032 & 0.032 & 0.000 & 5.06 & 0.004 & $* *$ \\
\hline UM1MD & 0.039 & 0.037 & 0.002 & 0.042 & 0.041 & 0.001 & 1.24 & 0.404 & \\
\hline UM1BL & 0.040 & 0.037 & 0.003 & 0.030 & 0.029 & 0.001 & 1.61 & 0.207 & \\
\hline LP2MD & 0.038 & 0.036 & 0.002 & 0.024 & 0.024 & 0.001 & 2.20 & 0.095 & \\
\hline LP2BL & 0.037 & 0.034 & 0.003 & 0.031 & 0.030 & 0.001 & 1.34 & 0.300 & \\
\hline LM1MD & 0.034 & 0.032 & 0.002 & 0.039 & 0.038 & 0.001 & 1.39 & 0.341 & \\
\hline LM1BL & 0.066 & 0.062 & 0.004 & 0.023 & 0.023 & 0.001 & 7.53 & 0.001 & ** \\
\hline
\end{tabular}

The assumption that variables were normally distributed for both immigrants and locals was examined using the Kolmogorov-Smirnov test $(\alpha=0.05)$ after standardization by Q-mode correction. The greater standard deviation is identified in bold. SD, standard deviation; Boot, bootstrapped standard deviation; Bias, estimated bias for uncorrected standard deviation. Significance level: *5\%; $* * 1 \%$; *** $0.1 \%$. 
Table 5. Univariate variance tests for Inariyama population

\begin{tabular}{|c|c|c|c|c|c|c|c|c|c|}
\hline \multirow{2}{*}{ Variable } & \multicolumn{3}{|c|}{ Immigrant $(n=3)$} & \multicolumn{3}{|c|}{ Local $(n=9)$} & \multirow{2}{*}{$F$-value } & \multirow{2}{*}{$P$-value } & \\
\hline & SD & Boot & Bias & SD & Boot & Bias & & & \\
\hline UP2MD & 0.038 & 0.031 & 0.007 & 0.010 & 0.010 & 0.001 & 10.40 & 0.006 & $* *$ \\
\hline UP2BL & 0.036 & 0.029 & 0.007 & 0.020 & 0.018 & 0.001 & 2.52 & 0.141 & \\
\hline UM1MD & 0.027 & 0.022 & 0.005 & 0.034 & 0.032 & 0.003 & 2.06 & 0.368 & \\
\hline UM1BL & 0.050 & 0.041 & 0.009 & 0.023 & 0.021 & 0.002 & 3.70 & 0.073 & \\
\hline LP2MD & 0.044 & 0.036 & 0.008 & 0.017 & 0.016 & 0.001 & 4.88 & 0.041 & * \\
\hline LP2BL & 0.017 & 0.014 & 0.003 & 0.020 & 0.018 & 0.002 & 1.76 & 0.412 & \\
\hline LM1MD & 0.052 & 0.042 & 0.009 & 0.009 & 0.008 & 0.001 & 25.11 & 0.000 & $* * *$ \\
\hline LM1BL & 0.038 & 0.031 & 0.007 & 0.028 & 0.026 & 0.002 & 1.39 & 0.303 & \\
\hline
\end{tabular}

The assumption that variables were normally distributed for both immigrants and locals was examined using the Kolmogorov-Smirnov test $(\alpha=0.05)$ after standardization by Q-mode correction. The greater standard deviation is identified in bold. SD, standard deviation; Boot, bootstrapped standard deviation; Bias, estimated bias for uncorrected standard deviation. Significance level: *5\%; ** $1 \%$; *** $0.1 \%$.

Table 6. Determinant ratios and randomization $P$-values

\begin{tabular}{ccc}
\hline Population & $\left|\mathrm{C}_{\text {Immigrant }}\right| /\left|\mathrm{C}_{\text {Local }}\right|$ & $\begin{array}{c}\text { Randomization } \\
P \text {-value }\end{array}$ \\
\hline Yoshigo & 4.77 & $0.012^{*}$ \\
Inariyama & 172.95 & $0.005^{* *}$ \\
\hline
\end{tabular}

Significance level: $* 5 \% ; * * 1 \% ; * * * 0.1 \%$.

\section{Discussion}

This study attempted to clarify interpopulation genetic relationships in the Jomon Atsumi Peninsula area by comparing dental morphological variation and human migration patterns. The results of correlation tests revealed that dental metric variations in the Yoshigo and Inariyama shell mounds were significantly associated with the distinction between immigrants and locals determined from the strontium isotope ratio of third molar enamel. This result suggested regional genetic heterogeneity among local populations in the Atsumi Peninsula area. Matsumura's (2000) dental metric study on skeletal remains from four sites in the Atsumi Peninsula area revealed that most individuals from these four sites did not form clear site-specific clusters. The results of the present study, however, suggest that the local gene pools had not been totally homogenized but mutual human migration between populations masked morphological distinction.

Excavated human remains may be an aggregate of individuals who lived at different times during the formation of the sites (Pietrusewsky, 2000; Stojanowski and Schillaci, 2006). In fact, most of the sites in the Atsumi Peninsula were formed from the later part of the Late Jomon period to the Final Jomon period (c. 3500-2300 BP), and both the Yoshigo and Inariyama shell mounds span several hundred years (Yamanouchi, 1952; Sugihara and Toyama, 1964; Kusaka et al., 2009). Observed biological variation can be changed through temporal processes (Owsley et al., 1982; Konigsberg, 1990a, b; Stojanowski, 2003, 2004, 2005a, b). However, the results of the present study indicated that human migration caused intrasite dental variation in the Atsumi Peninsula area. Since immigrants identified by strontium isotope ratio were first-generation individuals who had migrated from other populations, and the propor- tion of immigrants was 20-30\% (Kusaka et al., 2009, 2011), the temporal process of biological variation would be less prominent here than the effect of human migration.

PCA showed that five out of eight Yoshigo immigrants and all of the Inariyama immigrants were plotted outside of the confidence ellipses of each local variation. Overall, the immigrants were scattering more broadly than the locals and the distributions of them were not skewed in either the Yoshigo and Inariyama populations, suggesting that the immigrants did not share a common dental morphology. Furthermore, No. 540 was an outlier of the local Yoshigo distribution (Figure 4). Kusaka et al. (2009) raised the possibility that this individual, with a strontium isotope ratio close to the low end of the local variation, might actually have been an immigrant from the eastern inland area. The dental profile of No. 540, which was beyond the Yoshigo local dental distribution, would support this possibility.

All three Inariyama immigrants were outliers from the local dental variation. In the case of Inariyama, the local variation is small and outliers are more clearly identified. In this study, human migration based on isotope ratio was significantly associated with dental variation, and local individuals showed close morphological similarities each other in the PCA plots. Low dental variability of the Inariyama local population relative to the Yoshigo locals might be explained from either a greater effect of migration due to the longer existence of the Yoshigo shell mound, or a presence of a greater number of hidden immigrants. In any case, it is concluded that Inariyama locals showed relatively high genetic similarity among their small population.

The evaluation of dental variability in the local and immigrant groups suggests multiple origins of the immigrants. The results of the univariate analyses of between immigrants and locals within the Yoshigo and Inariyama shell mounds revealed a tendency of greater immigrant variation. The multivariate determinant ratio analyses also seemed to support these univariate results in both of the sites. It is important to note that those immigrants did not share a common dental morphology according to the PCA, and that the variance of the immigrants was significantly larger than that of the locals in both univariate and multivariate variance comparisons. This suggested that these immigrants had come from multiple parent populations, and these genetically distinct groups interacted with each other within and outside 
the Atsumi Peninsula area.

In general, migration among demes is considered to retard genetic differentiation. Therefore, the regional heterogeneity among the populations observed in the present study might have been caused by a lack of frequent interaction, insufficient duration for genetic admixture, or both. Regional genetic variation is expected to be high when local populations are relatively non-mobile and interpopulation gene flow is restricted due to geographical or social/cultural barriers. However, it seems unlikely that there were such barriers or infrequent gene flow in the relatively narrow Atsumi Peninsula area. In relatively small-scale, low-density, and kinbased societies where families migrate frequently, such as the Yanomamo of South America or the Semai of Malaysia, it has been shown that kin-structured migration increases genetic variation among populations (Fix, 1975, 1978, 1999, 2004; Smouse et al., 1981). Groups of kin hive off from local settlements to fuse with another population or establish new settlements of their own. Such a migrant group shares similar genotypes leading to biological relatedness, so that kinstructured migration can affect gene frequencies of both donor and recipient populations in smaller societies (Fix, 2004). Williams-Blangero (1989a, b) and Williams-Blangero and Blangero (1989) also found significant anthropometric microdifferentiaion between villages of the Jirel of Nepal despite migration among them, which might have been caused by nonrandom marital migration (clan-structured migration) related to kin-structured migration. It is conceivable that a similar mechanism has worked to establish microdifferentiation among the Jomon populations in the Atsumi Peninsula area. Interpopulation differentiation caused by nonrandom kin-structured migration can be seen in not only the Yanomamo and the Semai, which depend on swidden gardens for subsistence (Dentan, 1968; Neel, 1978; Fix, 1999), but also the Jirel, which is a settled agriculturalist population living in a restricted region (Bista, 1996). Although it is uncertain to what extent these populations are analogous to the Jomon people, who were sedentary huntergatherers, microdifferentiation among populations would result from nonrandom kin-structured migration upon marriage, and/or for fusing another groups or establishing new settlements. Jomon people in the Atsumi Peninsula area might have had a social organization in which kinship played a major role as social glue.

In the Jomon period, there were two periods of climatic cooling (Sakaguchi, 1989; Umitsu, 1994). The second cooling and fall of the sea level occurred during the Final Jomon period (Izeki, 1974; Ota et al., 1982, 1990; Umitsu, 1994), leading to a further reduction of the Jomon population throughout most of the Japanese archipelago (Koyama, 1978; Koyama and Sugito, 1984). However, in Aichi prefecture, the number and scale of the sites increased from the Late to Final Jomon period (Koyama, 1978). Settlements in the Atsumi Peninsula area might have benefited from access to shellfish in tidelands after the marine regression (Masuko, 1980; Iwase, 1991). In contrast, in the western part of the Aichi prefecture (Owari region) traces of human activity markedly decreased, suggesting a drastic population decline (Koumura, 1981; Masuko, 2001, 2006). These demographic changes may suggest population movements to the Atsumi
Peninsula area from neighboring areas (Masuko, 1980). Immigrants identified by strontium isotope analysis were members of the first generation who had migrated from distinct populations, and their genetic traits were different from those of each other and those of local populations. The parent populations of most of immigrants analyzed in the present study had not been included in the gene pools of each local population which had until then been constituted by interaction with other populations. Several researchers have suggested the possibilities that extraregional gene flow and migration, and/or population aggregation increased intracemetery heterogeneity (Key and Jantz, 1990; Griffin et al., 2001; Stojanowski, 2003, 2005b; Schillaci and Stojanowski, 2005). The present study could not verify the temporal change of genetic variation, and it may be conceivable that relatively high intrapopulation relatedness and migration among the surrounding and extraregional populations had occurred without environmental change. However, the biological and archeological findings here suggest that not only extraregional gene flow, but also the population aggregation from the surrounding areas associated with the climatic change of the Late to the Final Jomon period might have caused multiple genetically distinct populations to congregate in the Atsumi Peninsula area.

\section{Conclusion}

We investigated whether interpopulation genetic relationships in the Jomon Atsumi Peninsula area were homogeneous or heterogeneous, by combining dental metric and strontium isotope data about migratory patterns to investigate the population structure of the prehistoric society. The results showed that human migration patterns based on strontium isotope analysis were significantly correlated with dental metric variation, suggesting regional genetic heterogeneity between local populations. Although the difference of childhood home of Yoshigo and Inariyama individuals based on strontium isotope analysis did not completely correspond with the dental variability from PCA, at least 8 of 11 identified immigrants exhibited dental profiles atypical of each local variation. The variances of the immigrants were significantly larger than those of the locals, suggesting multiple origins of the immigrants. Microdifferentiation among populations in this area would have resulted from nonrandom kin-structured migration in the relatively small-scale, low-density, and kin-based societies as seen in the Yanomamo, the Semai or the Jirel populations, and/or population aggregation from surrounding areas in accordance with climatic change in the Final Jomon period.

We found regional heterogeneity among Jomon populations in the Atsumi Peninsula area, and reconstructed population dynamics in a temporally constrained small region by means of combination analysis of the spatial variance of childhood home based on strontium isotope analysis and phenotypic variance as a proxy for genetic variation, with full consideration of the archeological context. This study shows the usefulness of combining the phenotypic approach and geochemical methods for the reconstruction of prehistoric human societies in more detail. 


\section{Acknowledgments}

The authors wish to thank to Professor Emeritus K. Katayama (Kyoto University), and members of the Laboratory of Physical Anthropology, Kyoto University for helpful discussions and comments, and especially to C. Ramos for correcting the manuscript. We also thank Dr T. Nagaoka (St. Marianna University School of Medicine) and Prof. T. Hanihara (Kitasato University School of Medicine), for their thoughtful advice and comments on this study. Finally, we would like to thank two anonymous reviewers for their insightful comments and positive criticisms of our original manuscript. This study was supported in part by the Global COE Program A06 to Kyoto University.

\section{References}

Adachi N., Dodo Y., Ohshima N., Doi N., Yoneda M., and Matsumura H. (2003) Morphologic and genetic evidence for the kinship of juvenile skeletal specimens from a 2,000 yearsold double burial of the Usu-Moshiri site, Hokkaido, Japan. Anthropological Science, 111: 347-363.

Adachi N., Suzuki T., Sakaue K., Takigawa W., Ohshima N., and Dodo Y. (2006) Kinship analysis of the Jomon skeletons unearthed from a double burial at the Usu-Moshiri site, Hokkaido, Japan. Anthropological Science, 114: 29-34.

Bentley R.A. (2006) Strontium isotopes from the earth to the archaeological skeleton: a review. Journal of Archaeological Method and Theory, 13: 135-187.

Bentley R.A., Buckley H.R., Spriggs M., Bedford S., Ottley C.J., Nowell G.M., Macpherson C.G., and Pearson D.G. (2007) Lapita migrants in the Pacific's oldest cemetery: isotopic analysis at Teouma, Vanuatu. American Antiquity, 72: 645656.

Bista D.B. (1996) People of Nepal. Ranta Pustak Bhandar, Kathmandu.

Buikstra J.E., Frankenberg S.R., and Konigsberg L.W. (1990) Skeletal biological distance studies in American Physical Anthropology: recent trends. American Journal of Physical Anthropology, 82: 1-7.

Chevrud J. (1988) A comparison of genetic and phenotypic correlations. Evolution, 42: 958-968.

Chisholm B. and Koike H. (1999) Reconstructing prehistoric Japanese diet using stable isotopic analysis, Interdisciplinary perspectives on the origins of the Japanese. In: Omoto K. (ed.), Interdisciplinary Perspectives on the Origins of the Japanese. International Research Center for Japanese Studies, Kyoto, pp. 69-73.

Corruccini R.S. (1973) Size and shape in similarity coefficients based on metric characters. American Journal of Physical Anthropology, 38: 743-753.

Darroch J.N. and Mosimann J.E. (1985) Canonical and principal components of shape. Biometrika, 72: 241-252.

Dempsey P.J. and Townsend G.C. (2001) Genetic and environmental contributions to variation in human tooth size. Heredity, 86: 685-693.

Dentan R.K. (1968) The Semai: A Nonviolent People of Malaya. Holt, Rinehart and Winston, New York.

Efron B. (1981) Censored data and the bootstrap. Journal of the American Statistical Association, 76: 312-319.

Ezzo J.A., Johnson C.M., and Price T.D. (1997) Analytical perspectives on prehistoric migration: a case study from eastcentral Arizona. Journal of Archaeological Science, 24: 447466.

Fix A.G. (1975) Fission-fusion and lineal effect: aspects of the population structure of the Semai Senoi of Malaysia. American Journal of Physical Anthropology, 43: 295-302.
Fix A.G. (1978) The role of kin-structured migration in genetic microdifferentiation. Annals of Human Genetics, 41: 329339.

Fix A.G. (1999) Migration and Colonization in Human Microevolution. Cambridge University Press, Cambridge.

Fix A.G. (2004) Kin-structured migration: causes and consequences. American Journal of Human Biology, 16: 387-394.

Fujita T. (1949) On the standard of the measurement of teeth. Journal of the Anthropological Society of Nippon, 61: 27-32 (in Japanese).

Funahashi K. (2008) Tooth ablation [Basshi]. In: Kosugi Y., Nishida Y., Mizunoe K., Taniguchi Y., and Yano K. (eds.), Human and Society [Hito to shakai]. Douseisha, Tokyo, pp. 194-206 (in Japanese).

Green P.E. (1976) Mathematical Tools for Applied Multivariate Analysis. Academic Press, New York.

Griffin M.C., Lambert P.M., and Monahan-Driscoll E. (2001) Biological relationships and population history of native peoples in Spanish Florida and the American Southeast. In: Larsen C.S. (ed.), Bioarchaeology of Spanish Florida: The Impact of Colonialism. University Press of Florida, Gainesville, pp. 226-273.

Habu J. (2004) Ancient Jomon of Japan, Cambridge University Press, Cambridge.

Hartigan J.A. and Wong M.A. (1979) Algorithm AS 136: A Kmeans clustering algorithm. Applied Statistics, 28: 100-108.

Harunari H. (1979) Postmarital modes of residence of the Final Jomon period [Jomon banki no kongo kyoju kitei]. Journal of Faculty of Low and Literature of Okayama University [Okayama daigaku houbungakubu gakujyutsu kiyou], 40: 2563 (in Japanese).

Harunari H. (1986) Rules of residence in the Jomon period based on the analysis of tooth extraction. In: Pearson R.J., Barnes G.L., and Hutterer K.L. (eds.), Windows on the Japanese Past: Studies in Archaeology and Prehistory, Center for Japanese Studies. University of Michigan, pp. 293-310.

Hayden B. (1995) Pathways to power: principles for creating socioeconomic inequalities. In: Price T.D. and Feinman G.M. (eds.), Foundation of Social Inequality. Plenum Press, New York, pp. 15-86.

Hillson S. (1996) Dental Anthropology. Cambridge University Press, Cambridge.

Imamura K. (1996a) Prehistoric Japan: New Perspectives on Insular East Asia. University of Hawaii Press, Honolulu.

Imamura K. (1996b) Jomon and Yayoi: the transition to agriculture in Japanese prehistory. In: Harris D.R. (ed.), The Origins and Spread of Agriculture and Pastoralism in Eurasia. Smithsonian Institution Press, Washington, DC, pp. 442-464.

Iwase A. (1991) Sea-level change and shell mounds transition [Kaimen hendo to kaiduka no hensen]. In School Board of Toyohashi City (ed.), The Ichikisima jinja Site (I) [Ichikisima jinja iseki (I)]. School Board of Toyohashi City, Aichi, pp. 75-78 (in Japanese).

Izeki K. (1974) The sea level around 2000 BP in Japan [Nihon ni okeru 2000nen BP korono kaisuijun]. Journal of the faculty of letters, Nagoya University, History [Nagoya daigaku bungakubu kenyku ronshu (Shigaku)], 21: 1-22 (in Japanese).

Key P.J. and Jantz R.L. (1990) Statistical assessment of population variability: a methodological approach. American Journal of Physical Anthropology, 82: 53-59.

Kieser J.A. (1990) Human Adult Odontometrics: The Study of Variation in Adult Tooth Size. Cambridge University Press, Cambridge.

Kiyono K. (1925) A study of primitive people in Japan [Nihon genjin no kenkyu]. Okashoin, Tokyo (in Japanese).

Kiyono K. (1928) A study of the Stone Age Japanese [Nihon sekkijidaijin kenkyu]. Okashoin, Tokyo (in Japanese).

Kiyono K. (1969) Studies of Japanese Shell Mounds [Nihon kaizuka no kenkyu]. Iwanami-shoten, Tokyo (in Japanese).

Knudson K.J. and Price T.D. (2007) Utility of multiple chemical 
techniques in archaeological residential mobility studies: case studies from Tiwanaku-and Chiribaya-affiliated sites in the Andes. American Journal of Physical Anthropology, 132: 2539.

Kobayashi T., Kaner S., and Nakamura O. (2004) Jomon Reflection: Forager Life and Culture in the Prehistoric Japanese Archipelago. Oxbow Books, Oxford.

Kondo O. (1994) The skulls of Ubayama shell-mounds II. An analysis of intra-and inter-regional variation of the Jomon population. Anthropological Science, 102: 59-74.

Konigsberg L.W. (1988) Migration models of prehistoric postmarital residence. American Journal of Physical Anthropology, 77: 471-482.

Konigsberg L.W. (1990a) Analysis of prehistoric biological variation under a model of isolation by geographic and temporal distance. Human Biology, 62: 49-70.

Konigsberg L.W. (1990b) Temporal aspects of biological distance: serial correlation and trend in a prehistoric skeletal lineage. American Journal of Physical Anthropology, 82: 45-52.

Konigsberg L.W. and Buikstra J.E. (1995) Regional approaches to the investigation of past human biocultural structure, In: Beck L. (ed.), Regional Approaches to Mortuary Analysis. Plenum Press, New York, pp. 191-219.

Koumura H. (1981) The various stages of prehistoric culture in the Tokai region [Tokai senshi bunka no shodankai]. Printed as manuscript (in Japanese).

Koyama S. (1978) Jomon subsistence and population. Senri Ethnological Studies, 2: 1-65.

Koyama S. and Sugito S. (1984) A study of Jomon populationcomputer simulation analysis [Jomon jinko simulation]. Bulletin of the National Museum of Ethnology, 9: 1-39.

Kusaka S., Ikarashi T., Hyodo F., Yumoto T., and Katayama K. (2008) Variability in stable isotope ratios in two Late-Final Jomon communities in the Tokai coastal region and its relationship with sex and ritual tooth ablation. Anthropological Science, 116: 171-181.

Kusaka, S., Ando A., Nakano T., Yumoto T., Ishimaru E., Yoneda M., Hyodo F., and Katayama K. (2009) A strontium isotope analysis on the relationship between ritual tooth ablation and migration among the Jomon people in Japan. Journal of Archaeological Science, 36: 2289-2297.

Kusaka S., Nakano T., Yumoto T., and Nakatsukasa M. (2011) Strontium isotope evidence of migration and diet in relation to ritual tooth ablation: a case study from the Inariyama Jomon site, Japan. Journal of Archaeological Science, 38: $166-174$.

Lane R.A. and Sublett A.J. (1972) Osteology of social organization: residence pattern. American Antiquity, 37: 186-201.

Larsen C.S. (1997) Bioarchaeology: Interpreting Behavior from the Human Skeleton. Cambridge University Press, Cambridge.

Larsen C.S. (2002) Bioarchaeology: the lives and lifestyles of past people. Journal of Archaeological Research, 10: 119-166.

Manly B.F. (1994) Multivariate Statistical Methods: A Primer, 2nd edn. Chapman \& Hall, London.

Manly B.F. (1997) Randomization, Bootstrap and Monte Carlo Methods in Biology. Chapman \& Hall, London.

Masuko Y. (1980) A revisional study of last phase of the Late period and the Final period Jomon culture in the eastern Mikawa region (II) [Higashi mikawa ni okeru Jomon koukimatsu banki bunka no saikento (II)]. Bulletin of the Nagoya Archaeological Society [Kodaijin], 36: 13-24 (in Japanese).

Masuko Y. (2001) Various aspects of Jomon settlements in the Aichi prefecture [Aichiken ni okeru Jomon jidai shuraku no shoyousou]. In: Society for the Cultural Study of the Jomon Period (ed.), Various Aspects of Jomon Settlements in the Japanese Archipelago [Retto ni okeru Jomon jidai shuraku no shoyousou]. Society for the Cultural Study of the Jomon Period, Tokorozawa, pp. 451-468.

Masuko Y. (2006) The transition from Kaminari II pottery style to Sakurai and Inariyama pottery style [Kaminari II shiki kara sakurai shiki inariyama shiki heno iko]. Bulletin of the Nagoya Archaeological Society [Kodaijin], 66: 45-63.

Matsumura H. (2000) Dental Metric Variations between the Periods, Sites and Individuals of the Neolithic Jomon People in the Setouchi, Tokai, and Kanto Regions, Japan. Memoirs of the National Science Museum, Tokyo, 32: 175-187 (in Japanese with English summary).

Matsumura H. and Nishimoto T. (1996) Statistical analysis on kinship of the Nakazuma Jomon people using tooth crown measurements. Zoo-archaeology, 6: 1-17 (in Japanese with English summary).

Matsumura H., Ishida H., and Hashimoto H. (1996) Cranial and dental traits of the Nakazuma Jomon people from Ibaraki, Japan. Bulletin of the National Science Museum, Tokyo, D22: 1-26.

Montgomery J., Evans J.A., and Cooper R.E. (2007) Resolving archaeological populations with Sr-isotope mixing models. Applied Geochemistry, 22: 1502-1514.

Neel J.V. (1978) The population structure of an Amerindian tribe, the Yanomama. Annual Review of Genetics, 12: 365-413.

Ota Y., Matsushima Y., and Moriwaki H. (1982) Notes on the Holocene sea-level study in Japan - on the basis of 'Atlas of Holocene sea-level records in Japan.' The Quaternary Research, 21: 133-143 (in Japanese with English summary).

Ota Y., Umitsu M., and Matsushima Y. (1990) Recent Japanese research on relative sea level changes in the Holocene and related problems - review of studies between 1980 1988. The Quaternary Research, 29: 31-48 (in Japanese with English summary).

Owsley D.W., Bennett S.M., and Jantz R.L. (1982) Intercemetery morphological variation in Arikara crania from the Mobridge site (39WW1). American Journal of Physical Anthropology, 58: $179-185$.

Petersen H.C. (2000) On statistical methods for comparison of intrasample morphometric variability: Zalavár revisited. American Journal of Physical Anthropology, 113: 79-84.

Pietrusewsky M. (2000) Metric analysis of skeletal remains: methods and applications. In: Katzenberg M.A. and Saunders S.R. (eds.), Biological Anthropology of the Human Skeleton. Wiley-Liss, New York, pp. 375-415.

Powell J.F. and Neves W.A. (1999) Craniofacial morphology of the first Americans: pattern and process in the peopling of the New World. Yearbook of Physical Anthropology, 42: 153188.

Price T.D., Burton J.H., and Bentley R.A. (2002) The characterization of biologically available strontium isotope ratios for the study of prehistoric migration. Archaeometry, 44: 117-135.

R Development Core Team (2009) R: A Language and Environment for Statistical Computing. R Foundation for Statistical Computing, Vienna. http://www.R-project.org

Sakaguchi Y. (1989) The Natural History of Ozegahara [Ozegahara no shizenshi]. Chuoukouronsha, Tokyo (in Japanese).

Scherer A.K. (2007) Population structure of the Classic period Maya. American Journal of Physical Anthropology, 132: 367-380.

Schillaci M.A. and Stojanowski C.M. (2003) Postmarital residence and biological variation at Pueblo Bonito. American Journal of Physical Anthropology, 120: 1-15.

Schillaci M.A. and Stojanowski C.M. (2005) Craniometric variation and population history of the prehistoric Tewa. American Journal of Physical Anthropology, 126: 404-412.

Scott G.R. (1991) Dental anthropology. In: Dulbecco R. (ed.), Encyclopedia of Human Biology, Vol. 2: Br-De. San Diego and Tokyo, Academic Press, pp. 789-804.

Scott G.R. and Turner C.G. (1997) The Anthropology of Modern Human Teeth. Cambridge University Press, Cambridge.

Shinoda K., Matsumura H., and Nishimoto T. (1998) Genetical and morphological analysis on kinship of the Nakazuma Jomon people using mitochondrial DNA and tooth crown measurements. Zoo-archaeology, 11: 1-21 (in Japanese). 
Smouse P.E., Vitzthum V.J., and Neel J.V. (1981) The impact of random and lineal fission on the genetic divergence of small human groups: a case study among the Yanomama. Genetics, 98: 179-191.

Sokal R.R. and Rohlf F.J. (1995) Biometry, 3rd edn. W.H. Freeman, New York.

Spence M.W. (1974) Residential practices and the distribution of skeletal traits in Teotihuacan, Mexico. Man, 9: 262-273.

Stojanowski C.M. (2003) Differential phenotypic variability among the Apalachee populations of La Florida: A diachronic perspective. American Journal of Physical Anthropology, 123: 316-332.

Stojanowski C.M. (2004) Population history of native groups in pre- and postcontact Spanish Florida: Aggregation, gene flow, and genetic drift on the Southeastern US Atlantic coast. American Journal of Physical Anthropology, 123: 316-332.

Stojanowski C.M. (2005a) The bioarchaeology of identity in Spanish colonial Florida: Social and evolutionary transformation before, during, and after demographic collapse. American Anthropologist, 107: 417-431.

Stojanowski C.M. (2005b) Spanish colonial effects on Native American mating structure and genetic variability in northern and central Florida: evidence from Apalachee and western Timucua. American Journal of Physical Anthropology, 128: 273-286.

Stojanowski C.M. and Schillaci M.A. (2006) Phenotypic approaches for understanding patterns of intracemetery biological variation. American Journal of Physical Anthropology, 43: 49-88.

Sugihara S. and Toyama K. (1964) Sites along the Toyo-river in the Final Jomon Period [Toyogawa kayuiki niokeru Jomon jidai banki no iseki]. Kokogaku-shukan, 2: 37-101 (in Japanese).
Takahashi R. (2004) The front line of the study of Jomon Culture [Jomon bunka kenkyu no saizensen]. Waseda University, Tokyo (in Japanese).

Tanaka Y. (2001) Reconstructing Final Jomon post-marital residential patterns in western Japan. Bulletin of the Indo-Pacific Prehistory Association, 21: 43-48.

Temple D.H., Kusaka S., and Sciulli P.W. (2011) Patterns of social identity in relation to tooth ablation among prehistoric Jomon foragers from Yoshigo site, Aichi Prefecture, Japan. International Journal of Osteoarchaeology, 21: 323-335.

Tsude H. (2001) Yayoi farmers reconsidered: new perspectives on agricultural development in East Asia. Bulletin of the IndoPacific Prehistory Association, 5: 53-59.

Umitsu M. (1994) Late Quaternary Environment and Landform Evolution of Riverine Coastal Lowlands, Kokonshoin, Tokyo (in Japanese).

Watanabe H. (1990) Jomon Stratified Society [Jomon kaisouka shakai]. Rokuichi-shobo, Tokyo (in Japanese).

Williams-Blangero S. (1989a) Clan-structured migration and phenotypic differentiation in the Jirels of Nepal. Human biology, 61: 143-157.

Williams-Blangero S. (1989b) Phenotypic consequences of nonrandom migration in the Jirels of Nepal. American Journal of Physical Anthropology, 80: 115-125.

Williams-Blangero S. and Blangero J. (1989) Anthropometric variation and the genetic structure of the Jirels of Nepal. Human biology, 61: 1-12.

Yamanouchi S. (1952) The second trench. In: The Commission for the Protection of Cultural Properties Japan (ed.), The Shell Mounds of Yoshigo [Yoshigo kaiduka]. The Commission for the Protection of Cultural Properties Japan, Tokyo, pp. 93124. 